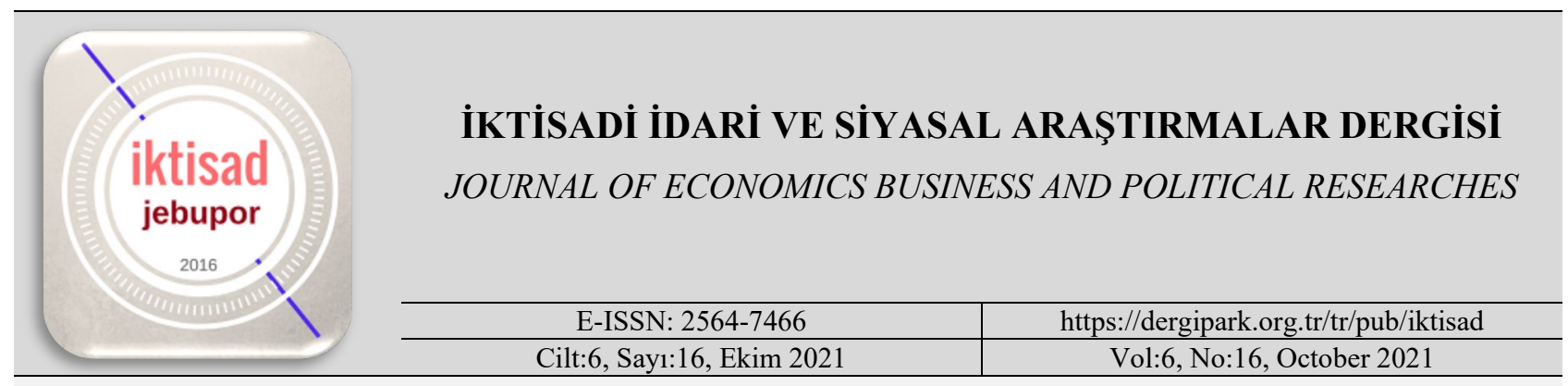

\title{
The Effect of Macroeconomic Factors on Non-Performing Loans: A Time Series Analysis for Turkey
}

$\bullet \bullet$
Makroekonomik Faktörlerin Sorunlu Krediler Üzerindeki Etkisi: Türkiye İçin Bir Zaman Serisi Analizi

DOI: https://doi.org/10.25204/iktisad.901062

Gizem BASS
Mehmet KARA $^{* *}$

\begin{abstract}
$\underline{\text { Article Info }}$

With the 2008 Global Crisis, Non-performing loans (NPLs) has dramatically increased in both Paper Type: Research Paper developed and developing countries. The excessive and uncontrolled increase in NPLs caused serious deterioration in the banking system. Particularly, in the countries, such as Turkey, where the banking system has a quite significant place in financial system, the deterioration in the banking system affects not only financial markets but also the economy in a negative way. In this research

Received:

22.03.2021 paper, the association between exchange rate, interest rate, total loan volume and production (output), which are macroeconomic variables expressed as external factors in the literature, and

Accepted:

07.10.2021

(C) 2021 JEBUPOR All rights reserved. NPLs is investigated for 2008:01-2017:12 period in Turkey. Unrestricted error correction model (UECM) and boundary test approach with the scope of ARDL analysis developed by Pesaran et al. (2001) is applied as an analysis method. Based on the analysis results, it is found that these macroeconomic variables and NPLs are cointegrated. Moreover, there is an economical and statistically significant relationship between interest rate and total loan volume and NPLs in both long and short term. In other words, it is determined that if interest rate and total loan volume increases, NPLs also move in the same direction.
\end{abstract}

Keywords: Non-performing loans (NPLs), total loan volume, interest rate, Turkey, ARDL analysis

Makale Bilgileri

Makale Türü: Araştırma Makalesi

Geliş Tarihi: 22.03.2021

Kabul Tarihi: 07.10 .2021

(C) 2021 IKTISAD

Tüm hakları saklıdır.

\section{(1) \$}

\section{$\ddot{O} \mathbf{z}$}

Ö

2008 Küresel Krizi ile takipteki krediler hem gelişmiş hem de gelişmekte olan ülkelerde önemli ölçüde artmıştır. Sorunlu kredilerdeki aşırı ve kontrolsüz artış, bankacılık sisteminde ciddi bir bozulmaya neden olmuştur. Bankacılık siteminin önemli olduğu Türkiye gibi ülkelerde sistemdeki bozulma sadece finansal piyasalart değil, ekonomiyi bir bütün olarak olumsuz yönde etkilemektedir. Bu çalışmada, literatürde dişsal faktörler olarak ifade edilen makroekonomik değişkenlerden döviz kuru, faiz oranı, toplam kredi hacmi ve üretim ile sorunlu krediler arasındaki ilişsi 2008:01-2017:12 dönemi Türkiye için incelenmiştir. Analiz yöntemi olarak Pesaran vd. tarafindan geliştirilen ARDL analizi kapsamında sinırsız hata düzeltme modeli (UECM) ve sinır testi yaklaşımı (2001) uygulanmıştır. Analiz sonuçları dĕ̆erlendirildiğinde, ele alınan makroekonomik değişkenlerin ve sorunlu kredilerin eşbütünleşik olduğu bulunmuştur. Ayrıca, faiz oranı ile toplam kredi hacmi ve sorunlu krediler arasında hem uzun hem de klsa vadede ekonomik ve istatistiksel olarak anlamlı bir ilişki olduğu sonucuna ulaşılmıştır. Yani faiz oranı ve toplam kredi hacmi artarsa sorunlu kredilerin de aynı yönde hareket ettiği tespit edilmiştir.

Anahtar Kelimeler: Sorunlu krediler, toplam kredi hacmi, faiz oranı, Türkiye, ARDL analizi

To Cite/ Atıf (APA): Baş, G. and Kara, M. (2021). The effect of macroeconomic factors on non-performing loans: A time series analysis for Turkey. Journal of Economics Business and Political Researches, 6(16), 335-347

\footnotetext{
* ORCID Arş. Gör., Hatay Mustafa Kemal Üniversitesi, İiBF, İktisat Bölümü, gizemercelik@mku.edu.tr
} ** ORCID Prof. Dr., Hatay Mustafa Kemal Üniversitesi, İ̈BF, İktisat Bölümü, mehmetkara@mku.edu.tr 


\section{Extended Abstract}

\section{Introduction and Research Questions and Purpose:}

Recently, non-performing loans (NPLs) in developed and developing markets have increased dramatically. And, as this increase is excessive and uncontrolled, it even led to the bankruptcy of the banking system as a whole. Specifically, in the countries, such as Turkey, where the banking system has a quite significant place in financial system, the deterioration in the banking system negatively impacts both the financial markets and the economy as a whole. In accordance with the Banking Law No. 5411, non-repayment of principal and interest payments exceeding 90 days are considered as NPLs. The repayment of the loans at this stage is possible through legal collection methods (Garanti Bank, 2005: 39).

This paper aims to investigate the interaction between exchange rate, interest rate, total loan volume and production (output) which are macroeconomic variables expressed as external factors in the literature, and NPLs, is examined both for the long and short term.

\section{Literature Review:}

In the literature, it can be concluded that there are several studies that examines the relationship between macroeconomic variables and NPLs. However, there is no consensus in the literature considering the studies' findings. Some of the studies indicated that the variables are directly related; on the other hand, it is stated that there is an inverse relationship. Also, it is surprisingly observed that there is no relationship between macroeconomic variables and NPLs. More importantly, the studies for Turkey, are not comprehensive and sufficient. Hence, this study provides empirical results for Turkey's economic conditions.

\section{Methodology:}

In the study, in order to be able to examine the relationship between macroeconomic factors and NPLs Augmented Dickey-Fuller (Dickey and Fuller, 1981) and Phillips-Perron unit root tests are performed to determine the stationarity of the variables. Furthermore, Unrestricted Error Correction Model (UECM) and boundary test approach within the scope of ARDL (Auto Regressive Distributed Lag) model developed by Pesaran et.al. (2001) are applied in order to examine the association between the variables. Since ARDL analysis method uses unrestricted error correction model, it provides more robust results comparing to other cointegration tests. The most important feature of the UECM is that it provides information about variables in both short term and long term. In addition, it provides reliable results even if few observations are analysed. Last but not least, CUSUM and CUSUMSQ graphs are provided to investigate the stability of long-term coefficients is searched for structural change.

\section{Results and Conclusions:}

Based on the findings obtained, it is concluded that there is a statistical and economical significant relationship between interest rate and total loan volume and NPLs in both long and short term. In the short and long term, an increase in interest rate cause NPLs to increase. The results of the analysis indicate that the rise in bank housing loan interest rate increases NPLs. In the study, it is also found that the increase in the total loan volume of the banking sector increases the NPLs. 


\section{INTRODUCTION}

Recently, non-performing loans (NPLs) in developed and developing markets have increased dramatically. And, as this increase is excessive and uncontrolled, it even led to the bankruptcy of the banking system as a whole. Specifically, in the countries, such as Turkey, where the banking system has a quite significant place in financial system, the deterioration in the banking system negatively impacts both the financial markets and the economy as a whole. In accordance with the Banking Law No. 5411, non-repayment of principal and interest payments exceeding 90 days are considered as NPLs. The repayment of the loans at this stage is possible through legal collection methods (Garanti Bank, 2005: 39).

With the 2008 crisis, the developments in the global markets adversely affected the countries' economies and led to the contraction of the credit market. Most importantly, it caused deterioration of asset quality in banks' balance sheet. In this context, NPLs indicates the quality of bank assets. The deterioration of asset quality in banks causes serious losses in the banking sector and is also considered as a signal of crisis (Reinhart and Rogoff, 2009).

In case of the loans becoming NPLs, the loan loss provisions allocated by the banks also rise and create cost for the bank. It means that the increase in NPLs increases the cost of banks and reduces their profitability. Furthermore, management and collection of NPLs increases operational costs of banks (Akbalık, 2009: 79). In addition to these, NPLs increases opportunity cost (Seval, 1990: 275276). The increase in funds allocated for NPLs (increase in loan loss provisions) prevents banks from converting their funding sources into alternative investments with higher returns. Thus, banks prefer not to provide new loans. In other words, credit supply decreases in case of increasing NPLs. Banks may resort to credit rationing in order to prevent deterioration of their balance sheet structures. The credit rationing of banks leads to a decrease in the total credit volume. Credit rationing is one of the methods used by banks to prevent adverse selection and moral hazard. Credit rationing could be in the form of banks reducing the loan supply at the current interest rate or completely rejecting the loan demand, instead of raising the interest rates and meeting the loan demand if the loan demand exceeds the loan supply (Köksel and Yöntem, 2014: 108).

NPLs, besides banking sector's asset quality, it indicates the ability of households and the real sector as economic decision makers to repay their debt. Especially, during recession, with increasing unemployment and loss of wealth, there is also an increase in NPLs (Inaba et.al., 2005: 114).

There are various factors that cause NPLs. In the literature, these factors are classified in two groups as internal and external. External factors, in general, are defined as macroeconomic indicators such as country's national income, unemployment rate, and inflation rate while internal factors are related to bank specific factors such as loan growth, loan rate, and loan to asset ratio (Gabeshi, 2017: 97). Also, reasons arising from the companies themselves such as operational failures makes difficult to repayment of the loans.

The studies in the literature, investigating the notion of non-performing loans is not sufficient. Furthermore, analysis of the studies includes a few number of variables. Since there is no comprehensive detailed study on this subject, macroeconomic factors are discussed by increasing the number of variables in this study. First of all, the objective of this paper is to determine whether macroeconomic factors have effects on non-performing loans (NPLs), and if they affect, to detect this effect. Hence, it is aimed to contribute to the literature. In this paper, the interaction between exchange rate, interest rate, total loan volume and production (output) which are macroeconomic variables expressed as external factors in the literature (Espinoza and Prasad, 2010; Love and Ariss, 2014; Nkusu, 2011; Klein, 2013; Belgrave et. al., 2012; Beaton et. al., 2016; Kjosevski and Petkovski, 2016; Hada et.al., 2020 ve Us, 2020) with NPLs, is examined both for the long and short term. The second section of the study includes a literature review, both theoretical and empirical. In the third section, theoretical model, dataset and method to analyse the relationship between macroeconomic factors 
and non-performing loans. Next, the empirical findings are examined, and the last section is the conclusion of this study.

\section{LITERATURE}

\subsection{Theoretical Literature}

An increase in the nominal exchange rate implies depreciation of domestic currency. In this case, with the increase in nominal exchange rate, the debt obligation of borrowers in terms of foreign currency increases in terms of national currency; therefore, increasing nominal exchange rate rises NPLs because of reduction of the capacity of firms to repay their debts (Nkusu, 2011: 8). However, in the literature (such as Zribi and Boujelbene, 2011 and Roy, 2014), there are also theoretical views that there is an inverse relationship between nominal exchange rate and NPLs. Considering these views, it can be stated that if the exchange rate increase, the profit performance of importing firms is affected in a negative way. It means that with the depreciation of the national currency, imported goods become more expensive and the sales of importing firms decrease (Castro, 2013; Nkusu, 2011). Hence, firms have difficulty repaying their loans. Additionally, in countries with small open economy, economic activities in the private sector are mainly carried out in terms of foreign currency. And the financial situation of the countries becomes strongly dependent on the exchange rate and is more affected by the fluctuations in the exchange rate (Jakubik, 2007: 71).

Interest rate for bank housing loans is quite significant for reaching the resources needed by households. Since increase in interest rate leads cost of borrowing to increase, housing demand of households is affected negatively. Therefore, it reduces the housing sales of firms (Castro, 2013: 375). Consequently, the risk of non-repayment of debts of households and firms arises (Beck et.al., 2013: 4-5; Kuutol, 2016). It can be considered that interest rate for housing loans and NPLs move in the same direction.

It is expected in theory, that increases in total loan volume negatively affects the quality of bank loans. Particularly, the abundance of global liquidity, which results from expansionary monetary policies implemented by major central banks such as FED, ECB and BOJ during global crisis, caused excessive amount of capital inflows to the countries with high return rates relatively such as Turkey. With this capital inflow, total loan volume significantly expanded (CBRT, 2010: 22). Most importantly, with 2008 global crisis, interest discounts and expansionary monetary policies implemented by the developed countries caused that global risk appetite increases and capital flows to emerging countries such as Turkey are the short-term. In these countries, both excessive loan growth and exchange rate fluctuations have occurred. This situation created a demand imbalance and rapidly deteriorated the balance of foreign trade (Kara and Afsal, 2018: 1824-1825). In fact, the excessive increase in total loan volume indicates a relationship between macroeconomic and financial shocks and financial instability risk. The deterioration of the quality of banks' loan portfolio is considered as one of the main causes of financial crises and problems in the banking system for both developed and developing countries. The excessive increase in the amount of banking sector's total loan volume implies that loans become sloppy. Also, providing random and sloppy loans brings the risk of non-repayment of these loans.

The other macroeconomic factor in this study is production (output). If the notion of money is defined including loans, the relationship between production and bank loans leads an argument that money supply is determined whether internally or externally. Based on the view that money is determined internally, monetary growth does not lead to an increase in production (output), on the contrary, it is assumed that there is a causal relationship from economic growth to money. For instance, accordingly the Real Business Cycle Theory, when production (output) increases, the demand of economic units for financial services increases, and banks respond to this demand by 
increasing their total loan volume (Bayraktar and Karaoğlu, 2016: 144-145). Also, the rapid increases in total loan volume provided by banks may lead to sloppy loans, which increase in NPLs.

\subsection{Empirical Literature}

The empirical literature on the relationship between macroeconomic variables and NPLs is given in Table 1. In Table 1, the studies that find the same and negative relation and no relationship between macroeconomic variables and NPLs are examined respectively.

Table 1: Related Literature

\begin{tabular}{|c|c|c|c|}
\hline Author(s) & Period/Country & Method & Results \\
\hline $\begin{array}{l}\text { Hess et.al. } \\
(2009)\end{array}$ & $\begin{array}{l}\text { 1980-2005/ } \\
32 \text { Australian Banks }\end{array}$ & $\begin{array}{l}\text { Panel Data } \\
\text { Analysis }\end{array}$ & $\begin{array}{l}\text { Analysis results indicate that macroeconomic indicators have } \\
\text { an effect on the quality of bank assets. It is also stated that poor } \\
\text { economic conditions increase NPLs. }\end{array}$ \\
\hline $\begin{array}{l}\text { Bofondi and } \\
\text { Ropele } \\
(2011)\end{array}$ & $\begin{array}{l}\text { 1990:Q1-2010:Q2/ } \\
\text { Italy }\end{array}$ & $\begin{array}{l}\text { Least Squares } \\
\text { Method }\end{array}$ & $\begin{array}{l}\text { NPLs are mainly influenced by the quality of loans provided } \\
\text { to households and firms, the general state of the economy, and } \\
\text { interest rates that represent borrowing costs. }\end{array}$ \\
\hline Carlos (2012) & $\begin{array}{l}\text { 2004-2012/ } \\
\text { Italy and Spain }\end{array}$ & $\begin{array}{l}\text { Panel Data } \\
\text { Analysis }\end{array}$ & $\begin{array}{l}\text { In the study, macroeconomic variables such as loan growth, } \\
\text { inflation, wages, unemployment and GDP are employed and it } \\
\text { is found that these variables have an impact on NPLs. }\end{array}$ \\
\hline $\begin{array}{l}\text { Louzis et.al. } \\
(2012)\end{array}$ & $\begin{array}{l}\text { 2003:Q1-2009:Q3/ } \\
9 \text { Great Greek Banks }\end{array}$ & $\begin{array}{l}\text { Dynamic Panel } \\
\text { Data Analysis }\end{array}$ & $\begin{array}{l}\text { It is stated that NPLs result from macroeconomic variables } \\
\text { such as income, interest rates and unemployment in the Greek } \\
\text { banking system. }\end{array}$ \\
\hline Mancka (2012) & $\begin{array}{l}\text { 2002:01-2010:12/ } \\
\text { Albania }\end{array}$ & $\begin{array}{l}\text { Multiple Linear } \\
\text { Regression }\end{array}$ & $\begin{array}{l}\text { It is concluded that the exchange rate of the euro and the dollar } \\
\text { significantly affects the NPLs in the Albanian banking system. }\end{array}$ \\
\hline $\begin{array}{l}\text { Jakubik and } \\
\text { Reininger } \\
(2013)\end{array}$ & $\begin{array}{l}\text { 2004-2012/ } \\
\text { Bulgaria, Croatia, Czech } \\
\text { Republic, Hungary, } \\
\text { Poland, Romania, Russia, } \\
\text { Slovakia, and Ukraine. }\end{array}$ & $\begin{array}{l}\text { Panel Data } \\
\text { Analysis }\end{array}$ & $\begin{array}{l}\text { In the study, macroeconomic variables are analysed, and it is } \\
\text { determined that there is a statistically inverse relationship } \\
\text { between real GDP and stock exchange index and NPLs. On } \\
\text { the other hand, there is statistically positive relationship } \\
\text { between private sector loans and nominal exchange rate and } \\
\text { NPLs. }\end{array}$ \\
\hline $\begin{array}{l}\text { Jordan } \\
\text { andTucker } \\
(2013)\end{array}$ & $\begin{array}{l}\text { 2002:09-2011:12/ } \\
\text { Bahamas }\end{array}$ & $\begin{array}{l}\text { Error Correction } \\
\text { Model }\end{array}$ & $\begin{array}{l}\text { Based on the findings obtained from the study, it can be stated } \\
\text { that economic growth, which is one of the macroeconomic } \\
\text { variables, causes a decrease in NPLs. }\end{array}$ \\
\hline Klein (2013) & $\begin{array}{l}\text { 1998-2011/ } \\
\text { Central, Eastern and South } \\
\text { Eastern Europe Countries }\end{array}$ & $\begin{array}{l}\text { Panel Data } \\
\text { Analysis }\end{array}$ & $\begin{array}{l}\text { NPLs tend to increase when unemployment increases, the } \\
\text { exchange rate depreciates, and inflation is high. }\end{array}$ \\
\hline $\begin{array}{l}\text { Shingjergji } \\
(2013)\end{array}$ & $\begin{array}{l}\text { 2005:Q1-2012:Q4/ } \\
\text { Albania }\end{array}$ & $\begin{array}{l}\text { Least Squares } \\
\text { Method }\end{array}$ & $\begin{array}{l}\text { In the analysis, it is found that there is a similar relationship } \\
\text { between economic growth, interest rate and exchange rate and } \\
\text { NPLs. }\end{array}$ \\
\hline $\begin{array}{l}\text { Karahanoğlu } \\
\text { and Ercan } \\
(2015)\end{array}$ & $\begin{array}{l}\text { 2005:01-2015:05/ } \\
\text { Turkey }\end{array}$ & $\begin{array}{l}\text { VAR and } \\
\text { Granger } \\
\text { Causality } \\
\text { Analysis }\end{array}$ & $\begin{array}{l}\text { On the basis of the analysis results, exchange rates are directly } \\
\text { related with non-performing loans. Also, exchange rate } \\
\text { Granger causes NPLs }\end{array}$ \\
\hline $\begin{array}{l}\text { Rahman and } \\
\text { Hamid (2019) }\end{array}$ & $\begin{array}{l}\text { 1997-2017/ } \\
\text { Bangladesh }\end{array}$ & $\begin{array}{l}\text { OLS Regression } \\
\text { Method }\end{array}$ & $\begin{array}{l}\text { In the study, it is concluded that exchange rate has positive } \\
\text { association with NPL. }\end{array}$ \\
\hline $\begin{array}{l}\text { Hada et.al. } \\
(2020)\end{array}$ & $\begin{array}{l}2009-2019 / \\
\text { Romaina }\end{array}$ & $\begin{array}{l}\text { Least Squares } \\
\text { Method }\end{array}$ & $\begin{array}{l}\text { It is found that exchange rate has been the main factor in } \\
\text { increasing the NPL ratio in the last } 5 \text { years in Romania. }\end{array}$ \\
\hline $\begin{array}{l}\text { Zribi and } \\
\text { Boujelbene } \\
(2011)\end{array}$ & $\begin{array}{l}\text { 1995-2008/ } \\
10 \text { Tunisian Banks }\end{array}$ & $\begin{array}{l}\text { Panel Data } \\
\text { Analysis }\end{array}$ & $\begin{array}{l}\text { It is indicated that the increases in exchange rates decrease the } \\
\text { NPLs in } 10 \text { Tunisian Banks. }\end{array}$ \\
\hline Roy (2014) & $\begin{array}{l}\text { 1995-2012/ } \\
\text { India }\end{array}$ & $\begin{array}{l}\text { Panel Data } \\
\text { Analysis }\end{array}$ & $\begin{array}{l}\text { The findings indicate that increases in real effective exchange } \\
\text { rate leads NPLs to decrease. }\end{array}$ \\
\hline Skarica (2014) & $\begin{array}{l}\text { 2007:Q3-2012:Q3/ } \\
7 \text { Central and Eastern } \\
\text { European Countries }\end{array}$ & $\begin{array}{l}\text { Panel Data } \\
\text { Analysis }\end{array}$ & Changes in exchange rates do not affect NPLs. \\
\hline Us (2020) & $\begin{array}{l}\text { 2002:Q4-2017:Q4/ } \\
31 \text { deposit banks in } \\
\text { Turkey }\end{array}$ & $\begin{array}{l}\text { Panel VAR } \\
\text { Analysis }\end{array}$ & $\begin{array}{l}\text { Analysis results indicated that for some periods, exchange rate } \\
\text { is significant; however, for some periods it is insignificant. } \\
\text { Therefore, the association between NPLs and exchange rate is } \\
\text { not consistent. }\end{array}$ \\
\hline
\end{tabular}


According to Table 1, it can be concluded that macroeconomic factors (exchange rate, interest rate, total loan volume and production) and NPLs moves in the same directions as most of the studies in the literature (Hess et.al., 2009; Bofondi and Ropele, 2011; Carlos, 2012; Louzis et.al. 2012; Mancka 2012; Jakubik and Reininger, 2013; Jordan and Tucker, 2013; Klein, 2013; Shingjergji, 2013; Karahanoğlu and Ercan, 2015; Rahman and Hamid, 2019 and, Hada et.al., 2020).

However, in the studies of Zribi and Boujelbene (2011) and Roy (2014), it is concluded that when exchange rate, which is one of the macroeconomic variables, increases, NPLs does not increase, on the contrary, it decreases. And it is interpreted in these studies as the increases in the exchange rate lead foreign exchange revenues of exporting firms to increase. Thus, the capability of these firms to repay their loans in terms of national currency increases and, NPLs decreases.

Lastly, in the studies of Skarica (2014), it is surprisingly observed that there is no relationship between macroeconomic variables and NPLs.

\section{THEORETICAL MODEL, DATASET AND METHOD}

In the study, the relationship between macroeconomic factors, which are nominal exchange rate, interest rate, total loan volume and production representing industrial output and NPLs is investigated, and the following model is conducted (also regarding the studies of Espinoza and Prasad, 2010; Love and Ariss, 2014; Nkusu, 2011; Klein, 2013; Belgrave et. al., 2012; Beaton et. al., 2016; Kjosevski and Petkovski, 2016; Hada et.al., 2020, and Us, 2020);

$$
\mathrm{NPL}_{\mathrm{t}}=\alpha_{1}+\alpha_{2} \mathrm{FX}_{\mathrm{t}}+\alpha_{3} \text { INTEREST }_{\mathrm{t}}+\alpha_{4} \text { CREDIT }_{\mathrm{t}}+\alpha_{5} \text { PRODUCTION }_{\mathrm{t}}+\mu_{\mathrm{t}},
$$

In the model, NPL represents non-performing loans, FX stands for nominal exchange rate (\$/TL), INTEREST indicates interest rate of housing bank loans, CREDIT implies banking sector's total loan volume and PRODUCTION means total industrial production index $(2015=100)$. And also, the probability values are analysed as regards 0,05 significance level.

The period between January 2008 and December 2017 is used in the analysis. Table 2 below represents the variables, their explanations, and the sources.

Table 2: Variables in the Study

\begin{tabular}{|l|l|l|}
\hline Code & Explanation & Source \\
\hline NPL & Non-performing Loans (NPLs) & $\begin{array}{l}\text { Banking Regulation and Supervision } \\
\text { Agency (BRSA) }\end{array}$ \\
\hline FX & Nominal Exchange Rate (\$/TL), & $\begin{array}{l}\text { Central Bank of the Republic of Turkey } \\
\text { (CBRT) }\end{array}$ \\
\hline INTEREST & Interest Rate of Housing Bank Loans (\%) & $\begin{array}{l}\text { Central Bank of the Republic of Turkey } \\
\text { (CBRT) }\end{array}$ \\
\hline CREDIT & $\begin{array}{l}\text { Banking Sector's Total Loan Volume (TRY) } \\
\text { (Thousand TRY) }\end{array}$ & $\begin{array}{l}\text { Central Bank of the Republic of Turkey } \\
\text { (CBRT) }\end{array}$ \\
\hline PRODUCTION & Total Industrial Production Index (2015=100) & $\begin{array}{l}\text { Central Bank of the Republic of Turkey } \\
\text { (CBRT) }\end{array}$ \\
\hline
\end{tabular}

In this study, Unrestricted Error Correction Model (UECM) and boundary test approach within the scope of ARDL (Auto Regressive Distributed Lag) model developed by Pesaran et.al. (2001) are applied in order to examine the association between the variables. In the literature, Engle-Granger (1987) and Johansen (1988) cointegration tests are frequently used as cointegration tests in cases where the variables are not stationary in their level but become stationary when their first differences are taken. Since ARDL analysis method uses unrestricted error correction model, it provides more robust results comparing to other cointegration tests. The most important feature of the UECM is that 
it provides information about variables in both short term and long term. In addition, it provides reliable results even if few observations are analysed (Narayan and Narayan, 2004).

\section{EMPIRICAL FINDINGS}

\subsection{Unit Root Tests}

Augmented Dickey-Fuller (Dickey and Fuller, 1981) and Phillips-Perron unit root tests are performed in the study.

Table 3: ADF Unit Root Test Results

\begin{tabular}{llll}
\hline Variables & Level & 1st Difference & Decision \\
\hline LNNPL & $-2.182(0.213)[\mathrm{c}]$ & $-6.802(0.000)[\mathrm{c}]$ & $\mathrm{I}(1)$ \\
LNFX & $-2.678(0.247)[\mathrm{c}+\mathrm{t}]$ & $-7.923(0.000)[\mathrm{c}]$ & $\mathrm{I}(1)$ \\
LNINTEREST & $-2.313(0.169)[\mathrm{c}]$ & $-6.392(0.000)[\mathrm{c}]$ & $\mathrm{I}(1)$ \\
LNCREDIT & $-1.226(0.661)[\mathrm{c}]$ & $-8.646(0.000)[\mathrm{c}]$ & $\mathrm{I}(1)$ \\
LNPRODUCTION & $-2.010(0.588)[\mathrm{c}+\mathrm{t}]$ & $-4.773(0.000)[\mathrm{c}]$ & $\mathrm{I}(1)$ \\
\hline
\end{tabular}

According to the results of ADF and PP unit root test, it is observed that all the variables, in PP unit root test except LNPRODUCTION, become stationary when their first differences are taken.

Table 4: PP Unit Root Test Results

\begin{tabular}{llll}
\hline Variables & Level & 1st Difference & Decision \\
\hline LNNPL & $-2.059(0.261)[\mathrm{c}]$ & $-6.868(0.000)[\mathrm{c}]$ & $\mathrm{I}(1)$ \\
LNFX & $-0.148(0.940)[\mathrm{c}+\mathrm{t}]$ & $-7.632(0.000)[\mathrm{c}]$ & $\mathrm{I}(1)$ \\
LNINTEREST & $-2.119(0.237)[\mathrm{c}]$ & $-6.354(0.000)[\mathrm{c}]$ & $\mathrm{I}(1)$ \\
LNCREDIT & $-0.913(0.780)[\mathrm{c}]$ & $-9.107(0.000)[\mathrm{c}]$ & $\mathrm{I}(1)$ \\
LNPRODUCTION & $-7.068(0.588)[\mathrm{c}+\mathrm{t}]$ & --- & $\mathrm{I}(0)$ \\
\hline
\end{tabular}

\subsection{Cointegration Test}

After performing unit root tests if there exists a cointegration relationship between the variables is examined. In the ARDL analysis method, the cointegration relationship is investigated with the boundary test approach. In other words, F test is performed to the first lags of dependent and independent variables to test the existence of cointegration relationship. After detecting the cointegration relationship between the series, ARDL models are established to examine long- and short-term relationships (Pesaran et. al., 2001).

The unrestricted error correction model established for the boundary test approach in the study is as follows:

$$
\begin{aligned}
& \Delta \text { NPLt }=\alpha 0+\alpha 1 \mathrm{t}+\Sigma \mathrm{mi}=1 \alpha 2 \mathrm{i} \Delta \text { NPLt }-\mathrm{i}+\Sigma \mathrm{m} \mathrm{i}=0 \alpha 3 \mathrm{i} \Delta \mathrm{FXt}-\mathrm{i}+\Sigma \mathrm{m} \mathrm{i}=0 \alpha 4 \mathrm{i} \Delta \text { INTERESTt }-\mathrm{i}+ \\
& \Sigma \mathrm{m} i=0 \alpha 5 \mathrm{i} \Delta \text { CREDITt } \mathrm{i}+\Sigma \mathrm{m} \text { i }=0 \alpha 6 \mathrm{i} \Delta \text { PRODUCTIONt-i }+\alpha 7 \text { NPLt- } 1+\alpha 8 \text { FXt- } 1+\alpha 9 \\
& \text { INTERESTt- } 1+\alpha 10 \text { CREDITt- } 1+\alpha 11 \text { PRODUCTIONt- } 1+\mu \mathrm{t} \text {, }
\end{aligned}
$$

In the UECM, $\mathrm{t}$ is the trend variable and $\mathrm{m}$ are the number of lags. In equation (2), $\alpha, \Delta$ and $\mu$ symbols denote the constant term, difference operator and error term, respectively. After estimating the regression equation, the determination of a long-term relationship is calculated with the Wald test (F statistic). In this model, the null hypothesis is that there is no cointegration relationship between dependent and independent variables; while the alternative hypothesis is that there is a cointegration relationship between the variables.

The calculated F-statistic is compared with the asymptotically derived significance levels in the studies of Pesaran et. al (2001). In this study, lower and upper values are given in case that all the 
variables are I (0) or I (1). If the calculated F statistic is smaller than the lower bound, then the null hypothesis cannot be rejected, and it is concluded that there is no cointegration. The other case is that the calculated F statistic value is greater than the upper limit of the critical values, in which case the null hypothesis stating that there is no long-run relationship between the variables can be rejected. If the calculated $\mathrm{F}$ statistic value takes a value between the upper and lower critical values, if it falls into the indeterminate region by another expression, in which case there can be no interpretation on whether or not there is cointegration. If a long-run relationship is determined between the variables by the boundary test, then ARDL models are constructed in order to be able to understand both long and short-term relationships among the variables (Akel and Gazel, 2014: 31).

Before performing the boundary test, optimal lag length is determined based on Schwarz Information Criteria. Then, boundary test within the scope of ARDL analysis method is performed in order to detect the existence of cointegration relationship between the variables.

Table 5: Boundary Test Results

\begin{tabular}{llll}
\hline $\mathbf{k}$ & F statistic & \%5 Critical Values & \\
\cline { 3 - 4 } & & Lower Bound & Upper Bound \\
4 & 5.901 & 2.86 & 4.01 \\
\hline
\end{tabular}

Based on the test results, it is found that there is a long-term relationship between the variables since the $F$ value is greater than the upper critical value.

\subsection{ARDL Model}

The ARDL model used in the analysis is as follows:

$$
\begin{aligned}
& \mathrm{NPL}_{\mathrm{t}}=\alpha_{0}+\alpha_{1 \mathrm{t}}+\sum^{\mathrm{m}}{ }_{\mathrm{i}=1} \alpha_{2 \mathrm{i}} \text { NPL }_{\mathrm{t}-\mathrm{i}}+\sum_{\mathrm{i}=0}^{\mathrm{n}} \alpha_{3 \mathrm{i}} \mathrm{FX}_{\mathrm{t}-\mathrm{i}}+\Sigma^{\mathrm{n}=0} \alpha_{4 \mathrm{i}} \text { INTEREST }_{\mathrm{t}-\mathrm{i}}+\sum_{\mathrm{i}=0}^{\mathrm{n}} \alpha_{5 \mathrm{i}} \text { CREDIT }_{\mathrm{t}-\mathrm{i}}+ \\
& \Sigma_{\mathrm{i}=0} \alpha_{6 \mathrm{i}} \text { PRODUCTION } \mathrm{t}_{\mathrm{i}-\mathrm{i}}+\mu_{\mathrm{t}}
\end{aligned}
$$

The following table represents the ARDL model and the diagnostic tests.

Table 6: ARDL $(2,0,0,0,0)$ Estimation Results

\begin{tabular}{|l|l|l|l|}
\hline Variables & Coefficients & t statistics & p-values \\
\hline LNNPL(-1) & 1.202 & 13.594 & 0.000 \\
\hline LNNPL(-2) & -0.253 & -2.909 & 0.004 \\
\hline LNFX & -0.041 & -1.022 & 0.308 \\
\hline LNINTEREST & 0.078 & 3.457 & 0.000 \\
\hline LNCREDIT & 0.090 & 3.441 & 0.000 \\
\hline LNPRODUCTION & -0.077 & -1.934 & 0.055 \\
\hline $\mathrm{C}$ & -1.228 & -2.914 & 0.004 \\
\hline \multicolumn{7}{|l|}{ Diagnostic Test Results } \\
\hline $\mathrm{R}^{2}$ & 0.997 & \\
\hline Adjusted $\mathrm{R}^{2}$ & 0.997 & \\
\hline $\mathrm{X}^{2}$ BG & $1.438[0.219]$ \\
\hline HET & $0.833[0.402]$ \\
\hline $\mathrm{X}^{2}$ RAMSEY & $0.501[0.480]$ \\
\end{tabular}

Breusch-Godfrey LM test $\left(X^{2} B G\right)$ is performed in order to detect autocorrelation problem in the model. Moreover, heteroscedasticity (HET) test indicates whether there is varying variance problem, and Ramsey RESET test $\left(X^{2} R A M S E Y\right)$ stands for model determination error detection. Lastly, values in parentheses indicate the probability values of results. 
Based on the diagnostic test results, it is concluded that there are no autocorrelation and heteroscedasticity problems and also the model is appropriate.

\subsubsection{Long-Term Relationship}

ARDL $(2,0,0,0,0)$ model's estimation results for the long term are given in the table below.

Table 7: Estimated Long-Term Coefficients of ARDL (2,0,0,0,0) Model

\begin{tabular}{lccc}
\hline Variables & Coefficients & t-statistics & p-values \\
\hline LNFX & -0.820 & -0.840 & 0.402 \\
LNINTEREST & 1.535 & 1.990 & 0.049 \\
LNCREDIT & 1.784 & 2.780 & 0.006 \\
LNPRODUCTION & -1.517 & -1.877 & 0.063 \\
C & -24.100 & -2.039 & 0.043 \\
\hline
\end{tabular}

Accordingly, analysis results, it is concluded that there is a statistically significant relationship between interest rate and total loan volume and NPLs. Moreover, it is found that the coefficient of interest rate and total loan volume are positive. Hence, in the long term, an increase in interest rate or total loan volume causes NPLs to increase.

\subsubsection{Short-Term Relationship}

The Error Correction Model, based on the ARDL analysis method, is established to examine the short-term relationship between the variables as follows:

$\Delta \mathrm{NPLt}=\alpha 0+\alpha 1 \mathrm{t}+\alpha 2$ ECt $-1+\Sigma \mathrm{mi}=1 \alpha 3 \mathrm{i} \Delta \mathrm{NPLt}-\mathrm{i}+\Sigma \mathrm{m} \mathrm{i}=0 \alpha 4 \mathrm{i} \Delta \mathrm{FXt}-\mathrm{i}+\Sigma \mathrm{m} \mathrm{i}=0 \alpha 5 \mathrm{i}$ $\triangle$ INTERESTt-i $\quad \Sigma \mathrm{m} \mathrm{i}=0 \alpha 6 \mathrm{i} \Delta$ CREDITt-i $\quad \Sigma \mathrm{m} \mathrm{i}=0 \alpha 7 \mathrm{i} \Delta$ PRODUCTIONt-i $+\mu \mathrm{t}$,

ECt-1 in the model represents the one period lagged value of the series of error terms obtained from the long-term relationship and the coefficient of this variable refers how much of the imbalance in the short term are balanced in the next term.

The results of the analysis within the scope of ARDL analysis established to investigate the short-term relationship between the variables are shown in Table 8 below.

Table 8: Error Correction Model Results Based on ARDL $(2,0,0,0,0)$

\begin{tabular}{|l|c|c|c|}
\hline Variables & Coefficients & t-statistics & p-values \\
\hline D(LNNPL(-1) & 0.253 & 2.909 & 0.004 \\
\hline D(LNFX) & -0.041 & -1.022 & 0.308 \\
\hline D(LNINTEREST) & 0.078 & 3.457 & 0.000 \\
\hline D(LNCREDIT) & 0.090 & 3.441 & 0.000 \\
\hline D(LNPRODUCTION) & -0.077 & -1.934 & 0.055 \\
\hline ECT(-1) & -0.050 & -2.844 & 0.005 \\
\hline
\end{tabular}

If the results of the short-term analysis are evaluated, it is found that there is a statistically economical significant relationship between interest rate and total loan volume and NPLs as in the long run. In other words, when interest rate or total loan volume increases, NPLs also increase. 


\subsubsection{CUSUM and CUSUMSQ Tests}

In addition, CUSUM and CUSUMSQ (Brown et.al., 1975: 149-155) graphs are examined in order to investigate the stability of long-term coefficients is examined for structural change, and the results are shown in Figure 1.

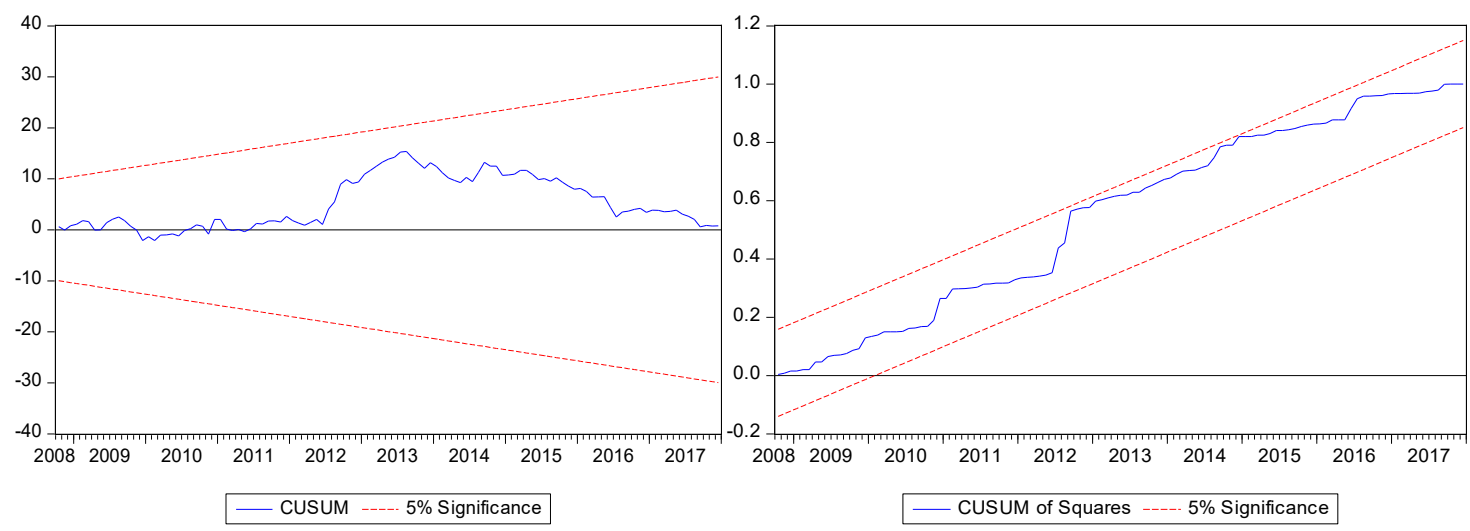

Figure 1: CUSUM Graphs

The CUSUM and CUSUMSQ graphs above indicate that there are no structural breaks related to the variables used in the analysis and that the estimated long-term coefficients are stable.

\section{CONCLUSION}

The definition and scope of non-performing loans vary in the countries, and it could be stated as the repayment agreement between the bank and the borrower is significantly disrupted, and the collection is delayed, and the possibility of loss arises. In this context, non-performing loans are referred as an indicator of asset quality in bank balance sheets. That is, a low NPL ratio in a bank indicates that the quality of bank assets is in good standing. In case of an increase in non-performing loans, the efficiency of the banking sector decreases, causing bank failures and even crises.

In this context, the objective of this paper is to determine whether macroeconomic factors have effects on non-performing loans, and if they affect, to detect this effect. And the nexus between exchange rate, interest rate, total loan volume and production, which are the macroeconomic variables defined as external factors in the literature, and NPLs is analysed by applying ARDL method for 2008:01-2017:12 period in Turkey.

Based on the findings obtained, it is concluded that there is a statistical and economical significant relationship between interest rate and total loan volume and NPLs in both long and short term. In the short and long term, an increase in interest rate cause NPLs to increase. Similarly, when total loan volume rises, NPLs also increases. Analysis results in the study are similar to the results in studies of Bofondi and Ropele (2011), Carlos (2012), Louzis et al. (2012) and Shingjergji (2013) in the literature.

The results of the analysis indicate that the rise in bank housing loan interest rate increases NPLs. It means that the increase in the housing loan interest rates increases the cost of borrowing, thus negatively affecting the housing demand of the household. Decreasing demand leads to an increase in NPLs by decreasing house sales of firms. In particular, loan interest rate is a quite significant indicator in economic activities for the countries where the financial system constitutes the major part of the economy such as Turkey.

In the study, it is also found that the increase in the total loan volume of the banking sector increases the NPLs. Specially, global liquidity abundance, resulting from excessive expansionary monetary policies implemented by major central banks in the world to overcome the 2008 crisis, 
caused intensive capital inflows to the countries providing a relatively high return such as Turkey. With this intensive capital inflow, total loan volume has expanded remarkably. The abundance of global liquidity led to sloppy and random loans; thus, the risk of non-repayment increases, and also NPLs increases.

\section{Notes}

In Table 3, expressions in parenthesis represent the probability values of the tests performed, [c] indicates constant, $[\mathrm{c}+\mathrm{t}]$ indicates constant and trend.

In Table 5, X2 BG, HET and X2 RAMSEY are statistics of autocorrelation, heteroscedasticity, and model construction error, respectively.

\section{REFERENCES}

Akbalık, M. (2009). Bankalarda stres testi. İstanbul: Avcıol Basım Yayın.

Akel, V. and Gazel, S. (2014). Döviz kurları ile BIST sanayi endeksi arasındaki eşbütünleşme ilişkisi: Bir ARDL sınır testi yaklaşımı. Erciyes Üniversitesi İktisadi ve Ídari Bilimler Fakültesi Dergisi, 44, 23-41

Bayraktar, Y. and Karaoğlu, E. (2016). Reel konjonktür teorisi, getirdiği yenilikler ve diğer konjonktür teorileri ile karşılaştırılması. Yalova Sosyal Bilimler Dergisi, 6(12), 140-162

Beaton, K., Myrvoda, A. and Thompson S. (2016). Non-performing loans in the ECCU: Determinants and macroeconomic impact. IMF Working Paper, 16/229

Beck, R., Jakubík, P. and Piloiu, A. (2013). Non-performing loans: What matters in addition to the economic cycle?. European Central Bank Working Paper, 1515, 1-34

Belgrave, A., G. Kester and M. Jackman. (2012). Industry specific shocks and 33 non-performing loans in Barbados. The Review of Finance and Banking, 4(2), 123-133

Bofondi, M. and Ropele, T. (2011). Macroeconomic determinants of bad loans: Evidence from Italian banks. Occasional Papers, 89, 1-42

Brown, R. L. Durbin, J. and Evans, J.M. (1975). Techniques for testing the consistency of regression relations over time. Journal of Royal Statistical Society, 37, 149-192

Carlos A. O. B. (2012). Macroecononic determinants of the NPLs in Spain and Italy. (Unpublished Dissertation). Submitted to The University of Leicester

Castro, V. (2013). Macroeconomic determinants of the credit risk in the banking system: The case of the GIPSI. Economic Modelling, 31, 672-683

CBRT. (2010). Financial Stability Report. Ankara: CBRT Publication

Dickey, D. A. and Fuller, W.A. (1981). Likelihood ratio statistics for autoregressive time series with a unit root. Econometrica Journal of the Econometric Society, 49(4), 1057-1072

Engle, R. F. and Granger, C.W.J. (1987). Cointegration and error correction: Representation, estimation and testing. Econometrica, 55, 251-76

Espinoza, R. and A. Prasad. (2010). Nonperforming Loans in the GCC Banking Systems and Their Macroeconomic Effects. IMF Working Paper No. 10/224

Gabeshi, K. (2017). The impact of macroeconomic and bank specific factors on Albanian NPLs. European Journal of Sustainable Development Research, 2(1), 95-102

Garanti Bank. (2005). Krediler ve dış ticaret, İstanbul: Eğitim Merkezi Dökümanları

Hada, T., Bărbut,ă-Mişu, N., Iuga, I. C. and Wainberg, D. (2020). Macroeconomic Determinants of Nonperforming Loans of Romanian Banks. Sustainability, 12, 1-19

Hess, K., Grimes, A. and Holmes, V. (2009). Credit losses in Australasian banking. The Economic Record, 85(270), 331-343

Inaba, N., Kozu, T., Sekine, T. and Nagahata, T. (2005). NPLs and the real economy: Japan's experience. BIS Papers, 22, 106-127 
Jakubik, P. (2007). Macroeconomic environment and credit risk. Czech Journal of Economics and Finance, 57(1-2), 60-78

Jakubik, P. and Reininger, T. (2013). Determinants of nonperforming loans in Central, Eastern and Southeastern Europe. Oesterreichische Nationalbank Focus on European Economic Integration, 3, 48-66

Johansen, S. (1988). Statistical analysis of cointegration vectors. Journal of Economics Dynamic and Control, 12(2-3), 231-254

Jordan, A. and Tucker, C. (2013). Assessing the impact of nonperforming loans on economic growth in the Bahamas. Monetaria, 371-400

Kara, M. and Afsal, M. S. (2018). The effectiveness of monetary policy instruments applied for financial stability in Turkey. Journal of the Human and Social Science Researches, 7(3), 18221847

Karahanoğlu, İ. and Ercan, H. (2015). The effect of macroeconomic variables on non-performing loans in Turkish banking sector. The Journal of International Social Research, 8(39), 883-892

Kjosevski, J. and Petkovski, M. (2016). Non-performing loans in the Baltic states: Determinants and macroeconomic effects. Baltic Journal of Economics, 17(2), 25-44

Klein, N. (2013). NPLs in CESEE: Determinants and impact on macroeconomic performance. IMF Working Paper, 13(72), 1-27.

Köksel, B. and Yöntem, T. (2014). Türk bankacılık sektöründe kredi tayınlaması: 2002-2013 dönemi üzerine bir uygulama. Erciyes Üniversitesi İktisadi ve İdari Bilimler Fakültesi Dergisi, 43, 107 131.

Kuutol, P.K. (2016). Exchange rate, non-performing loans and economic growth in Africa. (Unpublished Master's Thesis). Kwame Nkrumah University of Science and Technology (Knust) Institute of Social Sciences, Ghana

Louzis, D. P., Vouldis, A.T. and Metaxas, V.L. (2012). Macroeconomic and bank-specific determinants of NPLs in Greece: A comparative study of mortgage, business and consumer loan portfolios. Journal of Banking and Finance, 36, 1012-1027

Love, I. and R.T. Ariss. (2014). Macro-financial linkages in Egypt: a panel analysis of economic shocks and loan portfolio quality. Journal of International Financial Markets, Institutions and Money, 28, 158-181

Mancka A. (2012). The impact of national currency instability and the world financial crisis in the credit risk: The case of Albania. Journal of Knowledge Management, Economics and Information Technology, 8, 1-18

Narayan S. and Narayan P.K. (2004). Determinants of demand of Fiji's exports: An empirical investigation. The Developing Economics, 17(1), 95-112

Nkusu, M. (2011). Nonperforming loans and macrofinancial vulnerabilities in advanced economies. IMF Working Paper, 11(161), 1-28

Pesaran M.H., Shin, Y. and Smith, R.J. (2001). Bounds testing approaches to the analysis of level relationships. Journal of Applied Econometrics, 16(3), 289-326

Rahman, F. and Hamid Md. K. (2019). Impact of macroeconomic variables on non-performing loan in banking sector of Bangladesh. The Jahangirnagar Journal of Business Studies, 8(1), 157168

Reinhart, C. and Rogoff, K. (2009). This time is different. Princeton: Princeton University Press.

Roy, S. G. (2014). Determinants of non-performıng assets in India - panel regression. Eurasian Journal of Economics and Finance, 2(3), 69-78

Seval, B. (1990). Kredilendirme süreci ve kredi yönetimi. İstanbul: İstanbul Üniversitesi İşletme Fakültesi Yayınları

Shingjergji, A. (2013). The impact of macroeconomic variables on the non-performing loans in the Albanian banking system during 2005 - 2012. Academic Journal of Interdisciplinary Studies, 2(9), 335-339 
Skarica, B. (2014). Determinants of non-performing loans in Central and Eastern European Countries. Financial Theory and Practice, 38(1), 37-59

Us, V. (2020). A panel VAR approach on analyzing non-performing loans in the Turkish banking sector. Journal of BRSA Banking and Financial Markets, 14(1), 1-38

Zribi, N. and Boujelbene, Y. (2011). The factors influencing bank credit risk: The case of Tunisia. Journal of Accounting and Taxation, 3(4), 70-78 